\title{
Erratum to: Compatibility of metal additive manufactured tungsten collimator for SPECT/MRI integration
}

Amine M. Samoudi ${ }^{*}$, Karen Van Audenhaege ${ }^{2}$, Gunter Vermeeren ${ }^{1}$, Luc Martens ${ }^{1}$, Roel Van Holen² and Wout Joseph ${ }^{1}$

Any correspondence should be addressed to George Loudos, Supplement 'Proceedings of the 4th PSMR Conference on PET/MR and SPECT/MR' organizer: gloudos@teiath.gr

\section{Erratum}

Unfortunately, the original version of this article [1] contained an error. The author's name, 'Amine M Samoudi', was spelt incorrectly. This can be found corrected in the author list above.

\section{Author details}

${ }^{1}$ INTEC, Ghent University/iMinds, Ghent, Belgium. ${ }^{2}$ ELIS, Ghent University/iMinds, Ghent, Belgium.

Published online: 09 November 2015

\section{Reference}

1. Samudi AM, Van Audenhaege K, Vermeeren G, Luc M, Van Holen R, Joseph W. Compatibility of metal additive manufactured tungsten collimator for SPECT/MRI integration. EJNMMI Physics. 2015;2 Suppl 1:A52.
(C) 2015 Samoudi et al. Open Access This article is distributed under the terms of the Creative Commons Attribution 4.0 International License (http://creativecommons.org/licenses/by/4.0/), which permits unrestricted use, distribution, and reproduction in any medium, provided you give appropriate credit to the original author(s) and the source, provide a link to the Creative Commons license, and indicate if changes were made.
Submit your manuscript to a SpringerOpen ${ }^{\mathcal{O}}$ journal and benefit from:

- Convenient online submission

Rigorous peer review

- Immediate publication on acceptance

- Open access: articles freely available online

- High visibility within the field

- Retaining the copyright to your article

Submit your next manuscript at $>$ springeropen.com 